\title{
ARTHRITIS ASSOCIATED WITH ULCERATIVE COLITIS
}

\section{A CLINICAL AND PATHOLOGICAL STUDY}

\author{
BY \\ E. G. L. BYWATERS AND B. M. ANSELL \\ From the Canadian Red Cross Memorial Hospital, Taplow, Berks., \\ and the Postgraduate Medical School of London
}

The arthritis associated with ulcerative colitis has not been fully delineated, although Hench (1935) gave an excellent short characterization. Recent textbooks on arthritis omit mention of it (Copeman, 1955; Comroe, 1953) or give it a few lines only (Fletcher, 1951). In the comprehensive American and English language reviews published in the Annals of Internal Medicine by the American Rheumatism Association, no mention of it has been made since 1940 (Hench and others, 1940, 1941, 1948; Robinson and others, 1953, 1956), nor is it classified as such in the "Standard Nomenclature of Disease" approved by the American Rheumatism Association. This is possibly because it is thought to be merely rheumatoid arthritis occurring in ulcerative colitis, rather than a special entity (Hench and others, 1936). With the emergence of a nearly specific diagnostic test and more knowledge about this group of diseases, it seems opportune to review this problem again in the light of fourteen cases seen personally at the Special Unit for Juvenile Rheumatism, Canadian Red Cross Memorial Hospital and at the Postgraduate School, over the last 11 years, together with eight cases seen with Dr. Kellock at the Central Middlesex Hospital, and eight cases seen with Dr. Coghill at the West Middlesex Hospital. Data from seven other cases at these hospitals is also included, although these cases were not seen personally, making a total of $\mathbf{3 7}$ patients.

\section{Material and Methods}

Ulcerative colitis was diagnosed on the basis of a characteristic pathological, radiological, or sigmoidoscopic appearance, plus a compatible clinical history, including diarrhoea. The Rose-Waaler differential agglutination of sensitized sheep cells "D.A.T." has been carried out in its original form by Dr. Frances Scott at Taplow (Scott, 1952).

\section{Clinical Investigations}

Incidence of Joint Manifestations in Ulcerative Colitis

Ulcerative colitis is a comparatively uncommon disease and nowadays tends to be concentrated at hospitals where an active interest is taken in the special long-term medical, psychological, social, and surgical problems involved. The number of fresh in-patients diagnosed per year and fulfilling the above criteria during the last 10 to 11 years at Taplow, 1947-1956, and at Hammersmith, 19461956, was 38 (Taplow) and 71 (Hammersmith) out of a total turnover of 4,000 and 10,000 admissions per year respectively. This is a figure comparable with the 10.9 cases of ulcerative colitis per 10,000 admissions cited by Melrose (1955) from 23 teaching hospitals in Great Britain.

Arthritis and arthralgia occurred in only a few of these 109 patients. Thus, of the total 38 Taplow patients specifically referred to the general medical and surgical consultant staff with symptoms of colitis, only four showed or later developed joint signs and only two complained of arthralgia in a total mean period from onset to follow-up of 6.7 years. During the same period two patients were referred primarily because of their joints. At Hammersmith twelve patients had arthritis and four more had arthralgia only, out of the total of 71 seen between 1946 and 1956.

Thus these figures for joint involvement in ulcerative colitis considerably exceed most of those quoted in the literature (Table I, overleaf), but it is still a comparatively small proportion of the whole.

It is somewhat greater than the $2 \cdot 4$ per cent. estimated by Kellgren, Lawrence, and Aitken-Swan (1953) or the $7 \cdot 8$ per cent. estimated by Kellgren and Lawrence (1956) for the incidence of rheumatoid arthritis in adults based on survey work. 
TABLE I

INCIDENCE OF ARTHRITIS IN ULCERATIVE COLITIS

\begin{tabular}{|c|c|c|c|c|c|}
\hline \multicolumn{2}{|c|}{$\begin{array}{c}\text { Place of } \\
\text { Investigation }\end{array}$} & Authors & Date & $\begin{array}{c}\text { Total No. } \\
\text { of Cases }\end{array}$ & $\begin{array}{c}\text { Percentage with } \\
\text { Arthritis }\end{array}$ \\
\hline Mayo Clinic & . & Bargen & Cited by Hench, 1935 & 1,500 & 4 \\
\hline Oxford .. & $\cdots \quad \cdots$ & Rice-Oxley and Truelove & 1950 & 129 & $5 \cdot 4$ \\
\hline Mayo Clinic & . & Sloan, Bargen, and Gage & 1950 & 2,000 & $7 \cdot 7$ \\
\hline New York, $M$ & lontefiore & Brown, Kasich, and Weingarten & 1951 & 147 & $7 \cdot 5$ \\
\hline Minneapolis & $\cdots$ & Dennis and Karlson & 1952 & 267 & $7 \cdot 1$ \\
\hline Birmingham & . & Brooke & 1956 & 131 & 13 \\
\hline Boston ... & . & Kirsner, Palmer, Maimon, and Ricketts & 1948 & 100 & 8 \\
\hline Boston .. & . & Kirsner, Sklar, and Palmer & 1957 & 180 & 22 \\
\hline
\end{tabular}

\section{Age and Sex Incidence}

Of the 37 patients reviewed here (Table II, opposite), 28 were females ( 76 per cent.) compared with a sex ratio of $68 \mathrm{~F} . / 41 \mathrm{M}$. for ulcerative colitis as a whole at Taplow and Hammersmith (62 per cent.), and 62 per cent. in the recent series of Cullinan and MacDougall (1957), and a ratio of $2: 1$ (64 per cent. females) for rheumatoid arthritis (Lewis-Faning, 1950).

The mean age at onset of the ulcerative colitis was 26.7 years (male) and 32.9 years female (range 13 to 44 and 8 to 67 respectively). The age at onset of the arthritis was 10 to 48 yrs in the nine males (mean 26.3) which was slightly less than the range of 8 to 67 in the 28 females (mean $34 \cdot 8$ ).

Ulcerative colitis preceded arthritis in seventeen patients (range 16 years to 1 week; mean 4 yrs $7 \mathrm{mths}$ ); the onset was simultaneous in four patients, and in seven the arthritis preceded the colitis by intervals of from 8 yrs to 7 wks (mean $36 \mathrm{mths}$ ). All these groups included children, and also patients

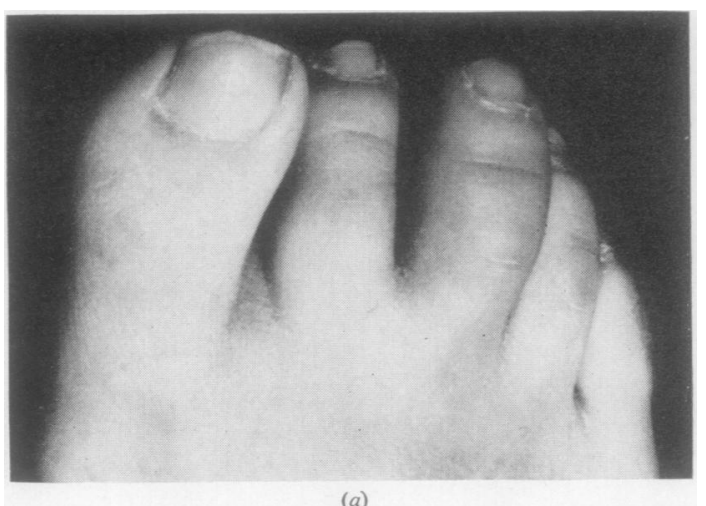

Fig. 1. Case $8(a)$.-Toe involvement in first attack of acute arthritis 10 years after onset of ulcerative colitis. with remissions of joint symptoms such as are only? rarely seen in ordinary rheumatoid arthritis.

In previously reported cases, arthritis has been known to precede colitis by as much as 5 years 8 (Comfort, Bargen, and Morlock, 1938).

\section{Special Aspects of Joint Involvement}

(a) Joints Involved.-The joints involved most $\underset{\bar{D}}{\overparen{2}}$ frequently were the knees and ankles. Finger $\overrightarrow{0}$ joints were not so frequently affected as in rheumas 0 toid arthritis, but involvement of the distal and proximal interphalangeal toe joints was seen in four. patients (e.g. Case 8, Table II, Fig. $1 a, b, c)$. In ou experience the proximal and distal interphalangeal joints of the toes are very seldom involved in typical rheumatoid arthritis; when they are involved a search should be conducted for signs of psoriasis, $\overline{\bar{O}}$ colitis, or Reiter's syndrome. In Case 2 (Table II), suspected of having rheumatic fever on account of a migratory polyarthritis with effusion into one knee and a high fever, this feature led us to suspect
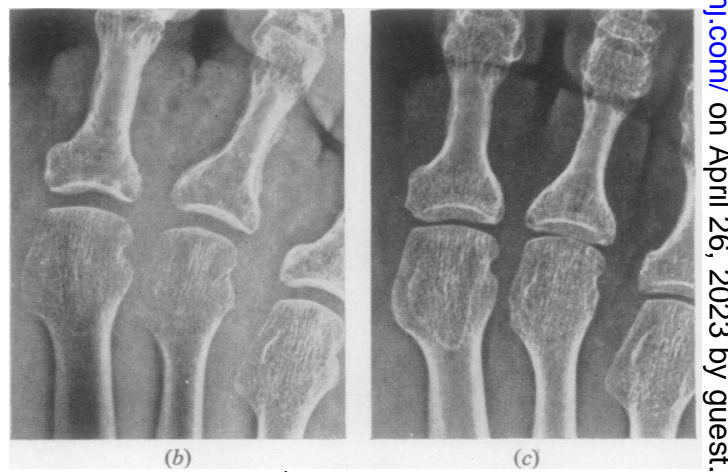

(b).- $X$ ray of foot at onset of arthritis, showing periostitis and

(c).- $X$ ray of foot 7 years after acute arthritis, showing disappearance of periostitis and healed erosion. 
TABLE II

PARTICULARS OF 37 CASES OF ULCERATIVE COLITIS

\begin{tabular}{|c|c|c|c|c|c|c|c|c|c|c|}
\hline \multirow{3}{*}{$\begin{array}{l}\text { Case } \\
\text { No. }\end{array}$} & \multicolumn{4}{|c|}{ When First Seen } & \multirow{3}{*}{ E.N. } & \multirow{3}{*}{$\frac{\begin{array}{c}\text {-Ectomy (EC) } \\
\text {-Ostomy (OS) }\end{array}}{\text { Operation }}$} & \multicolumn{3}{|c|}{ Follow-up Examination } & \multirow{3}{*}{$\begin{array}{c}\text { Differential } \\
\text { Agglutination } \\
\text { Test }\end{array}$} \\
\hline & \multirow[b]{2}{*}{ Sex } & \multirow{2}{*}{$\begin{array}{l}\text { Age } \\
\text { (yrs) }\end{array}$} & \multicolumn{2}{|c|}{ Duration of } & & & \multirow{2}{*}{$\begin{array}{l}\text { Yrs from } \\
\text { Date of First } \\
\text { Observation }\end{array}$} & \multicolumn{2}{|c|}{$\begin{array}{c}\text { Joint Residua at } \\
\text { Last Examination }\end{array}$} & \\
\hline & & & $\begin{array}{c}\text { Joint } \\
\text { Involvement }\end{array}$ & Colitis & & & & Clinical & $\begin{array}{l}\text { Radio- } \\
\text { logical }\end{array}$ & \\
\hline 1 & $\mathbf{M}$ & 16 & 6 yrs & (8 mths later) & 0 & - & 3 & 0 & + & $1: 4$ \\
\hline 2 & $\mathbf{F}$ & 18 & $1 \mathrm{mth}$ & $1 \mathrm{mth}$ & 0 & - & 4 & 0 & 0 & $1: 2$ \\
\hline 3 & $\mathbf{F}$ & 38 & 3 mths & $21 \mathrm{mths}$ & 0 & $\begin{array}{l}\text {-OS } \\
-\mathrm{EC}\end{array}$ & 6 & + & + & $1: 2$ \\
\hline 4 & $\mathbf{M}$ & 35 & $14 \mathrm{mths}$ & $18 \mathrm{mths}$ & 0 & - OS & (Died after 2 yrs) & 0 & + & - \\
\hline 5 & $\mathbf{F}$ & 24 & (1 yr later) & 6 mths & 0 & $\begin{array}{l}\text {-OS } \\
-\mathrm{EC}\end{array}$ & 7 & + & 0 & $1: 2$ \\
\hline 6 & $\mathbf{F}$ & 57 & $1 \mathrm{mth}$ & 4 mths & 0 & - OS & 10 & + & 0 & $1: 4$ \\
\hline 7 & $\mathbf{F}$ & 36 & 5 mths & $19 \mathrm{mths}$ & 0 & - & 1 & + & + & $1: 2$ \\
\hline 8 & $\mathbf{F}$ & 44 & 6 mths & 10 yrs & 0 & 一 & 7 & 0 & + & $1: 2$ \\
\hline 9 & $\mathbf{F}$ & 29 & $18 \mathrm{mths}$ & 5 yrs & 0 & - & 9 & + & + & - \\
\hline 10 & $\mathbf{F}$ & 54 & 3 yrs & 4 yrs & 0 & - & (Died after 5 yrs) & 0 & 0 & 一 \\
\hline 11 & $\mathbf{F}$ & 57 & 14 yrs & 14 yrs & + & - & Not traced & 0 & 0 & - \\
\hline 12 & $\mathbf{F}$ & 44 & 5 yrs & 5 yrs & 0 & - & Not traced & + & + & - \\
\hline 13 & $\mathbf{F}$ & 14 & 6 yrs & 6 yrs & 0 & - & 6 & + & + & $1: 2$ \\
\hline 14 & $\mathbf{F}$ & 42 & $18 \mathrm{yrs}$ & 23 yrs & + & - & 9 & + & + & $1: 2$ \\
\hline 15 & $\mathbf{M}$ & 13 & (2 mths later) & $1 \mathrm{mth}$ & + & - & 3 & 0 & 0 & $1: 8$ \\
\hline 16 & $\mathbf{M}$ & 13 & $1 \mathrm{yr}$ & ?1 yr & 0 & - & 4 & 0 & 0 & $1: 8$ \\
\hline 17 & $\mathbf{F}$ & 12 & (7 mths later) & 3 wks & 0 & Partial -EC & Not traced & 0 & 0 & 一 \\
\hline 18 & $\mathbf{F}$ & 46 & 3 yrs + & 10 mths & 0 & $-\mathrm{EC}$ & (Died after $4 \mathrm{mths})$ & + & 0 & - \\
\hline 19 & $\mathbf{F}$ & 35 & 4 wks & $11 \mathrm{yrs}$ & $\mathbf{0}$ & - & $6 \mathrm{mths}$ & + & 0 & $1: 2$ \\
\hline 20 & $\mathbf{M}$ & 24 & 9 days & (12 mths later) & 0 & - & 1 & 0 & + & $1: 4$ \\
\hline 21 & $\mathbf{F}$ & 27 & $1 \mathrm{mth}$ & 4 mths & + & $-\mathrm{EC}$ & 5 & 0 & + & $1: 2$ \\
\hline 22 & $\mathbf{F}$ & 25 & 4 mths & 13 yrs & + & $-O S$ & 1 & 0 & 0 & $1: 1$ \\
\hline 23 & $\mathbf{F}$ & 53 & 2 wks & 16 yrs & + & - & 1 & 0 & 0 & $1: 2$ \\
\hline 24 & $\mathbf{F}$ & 52 & 2 yrs & $18 \mathrm{mths}$ & 0 & $-\mathrm{OS}$ & 9 & + & + & $1: 64$ \\
\hline 25 & $\mathbf{F}$ & 40 & 7 mths & $1 \mathrm{mth}$ & 0 & - & 2 & 0 & 0 & $1: 1$ \\
\hline 26 & $\mathbf{F}$ & 21 & 2 days & 3 wks & + & $-\mathrm{EC}$ & 5 & 0 & 0 & $1: 2$ \\
\hline 27 & $\mathbf{F}$ & 47 & (6 yrs later) & 3 yrs & 0 & - & 7 & 0 & 0 & $1: 2$ \\
\hline 28 & $\mathbf{F}$ & 36 & $1 \mathrm{mth}$ & 4 mths & 0 & - & 5 & + & + & - \\
\hline 29 & $\mathbf{M}$ & 35 & $1 \mathrm{yr}$ & 7 yrs & 0 & $-\mathrm{EC}$ & 5 & 0 & 0 & - \\
\hline 30 & $\mathbf{F}$ & 33 & (8 mths later) & 5 wks & 0 & - OS & 1 & + & + & $1: 4$ \\
\hline 31 & $\mathbf{F}$ & 22 & 10 yrs & 10 yrs & 0 & (Partial -EC) & 4 & 0 & 0 & $1: 8$ \\
\hline 32 & $\mathbf{F}$ & 67 & 1 wk & 1-2 wks & 0 & - & 3 & 0 & 0 & $1: 4$ \\
\hline 33 & $\mathbf{M}$ & 44 & (4 yrs later) & 1-2 wks & 0 & - & 12 & + & + & $1: 2$ \\
\hline 34 & $\mathbf{F}$ & 51 & 8 yrs & 2 wks & 0 & - & 10 & + & + & $1: 256$ \\
\hline 35 & $\mathbf{M}$ & 50 & 7 yrs & 8 yrs & 0 & - & 3 & + & + & $1: 2$ \\
\hline 36 & $\mathbf{M}$ & 22 & 2-3 wks & $18 \mathrm{mths}$ & + & - & 6 & 0 & 0 & $1: 1,024$ \\
\hline 37 & $\mathbf{F}$ & 36 & $1 \mathrm{mth}$ & (3 mths later) & 0 & - & 7 & 0 & 0 & $1: 4$ \\
\hline
\end{tabular}

$£$ 
ulcerative colitis before any obvious diarrhoea had occurred, and the diagnosis was confirmed at this stage by barium enema. In the following 4 years the patient had three more attacks of arthritis with severe colitic symptoms in two of them, but she is now well and has no residua. When arthritis resolves, as it does not infrequently, leaving no clinical residua, $x$-ray examination may reveal small residual healed erosions, such as are seen in Fig. 1(c).

Sacro-iliac involvement was seen in six patients, in none of whom was there limitation of back movement. We were unable to distinguish this change radiologically from that of ankylosing spondylitis. One of these patients also had psoriasis, but this antedated the colitis by 11 years and the arthritis by 15 years. Although the proximal interphalangeal joints of the fingers were involved, the distal joints of the toes were not affected and the arthritis subsided with the colitis; the psoriasis, however, persisted. In Cases 1 and 13 (Table II) the sub-Achilles bursa was involved, which is more characteristic of Reiter's disease or ankylosing spondylitis (Bywaters, 1954), though it is sometimes seen in rheumatoid arthritis. Both showed sacro- iliac involvement (Fig. 2). In Case 13 erosions of $\frac{\text { गु }}{\widehat{0}}$ the ischia and the great trochanters (symptomless) and pseudo-cystic lesions in the acetabular margins were seen radiologically (Fig. 3, opposite), and in the ${ }^{\circ}$. neck there was an anterior erosion of the third cervical vertebra (Fig. 4, opposite) of the types? described by Romanus and Ydén (1955).

(b) Course and Clinical Pattern of Joint Involve-듬 ment.-More characteristic than the particular $\frac{\bar{c}}{5}$ joints affected was the course and clinical pattern $\varnothing_{\varrho}$ of joint involvement. This, in most instances, was a recurrent mild synovitis, attacking first one $\rightarrow$ or two and then more joints, subsiding in some as. it affected others. Because of this the disease was $\vec{\omega}$ difficult to differentiate from rheumatic fever, ando in fact some of our cases were initially labelled as $\frac{0}{2}$ such. However, the synovitis tended to recur, localizing in one or two of the joints that had been affected longest. The migratory and recurrent: nature of the polyarthritis is well illustrated in? Case 13, in which the areas affected were thoseo usually seen in ankylosing spondylitis. In thisparticular case a remarkable feature was the excel- $c$ lent general condition despite a persistently high

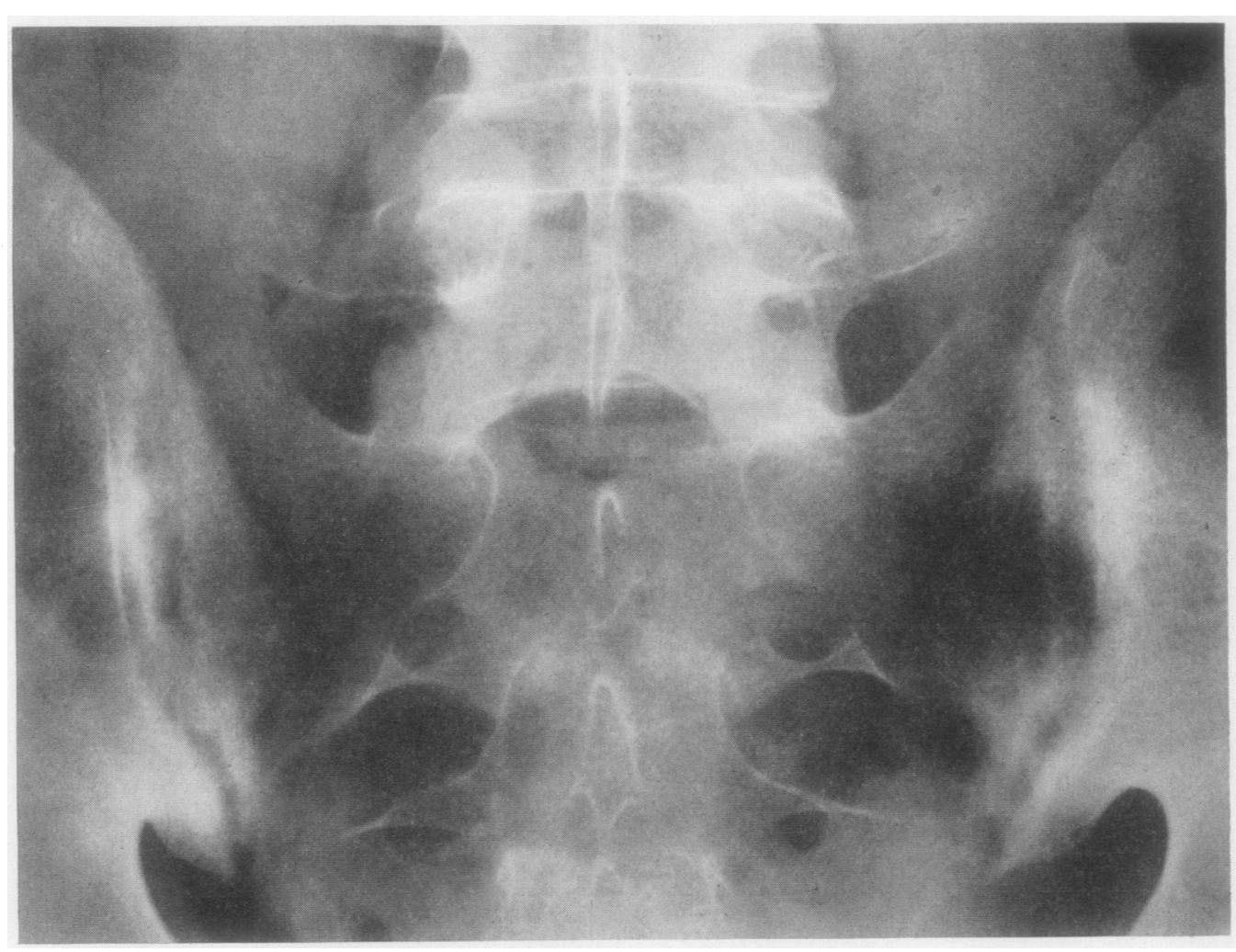




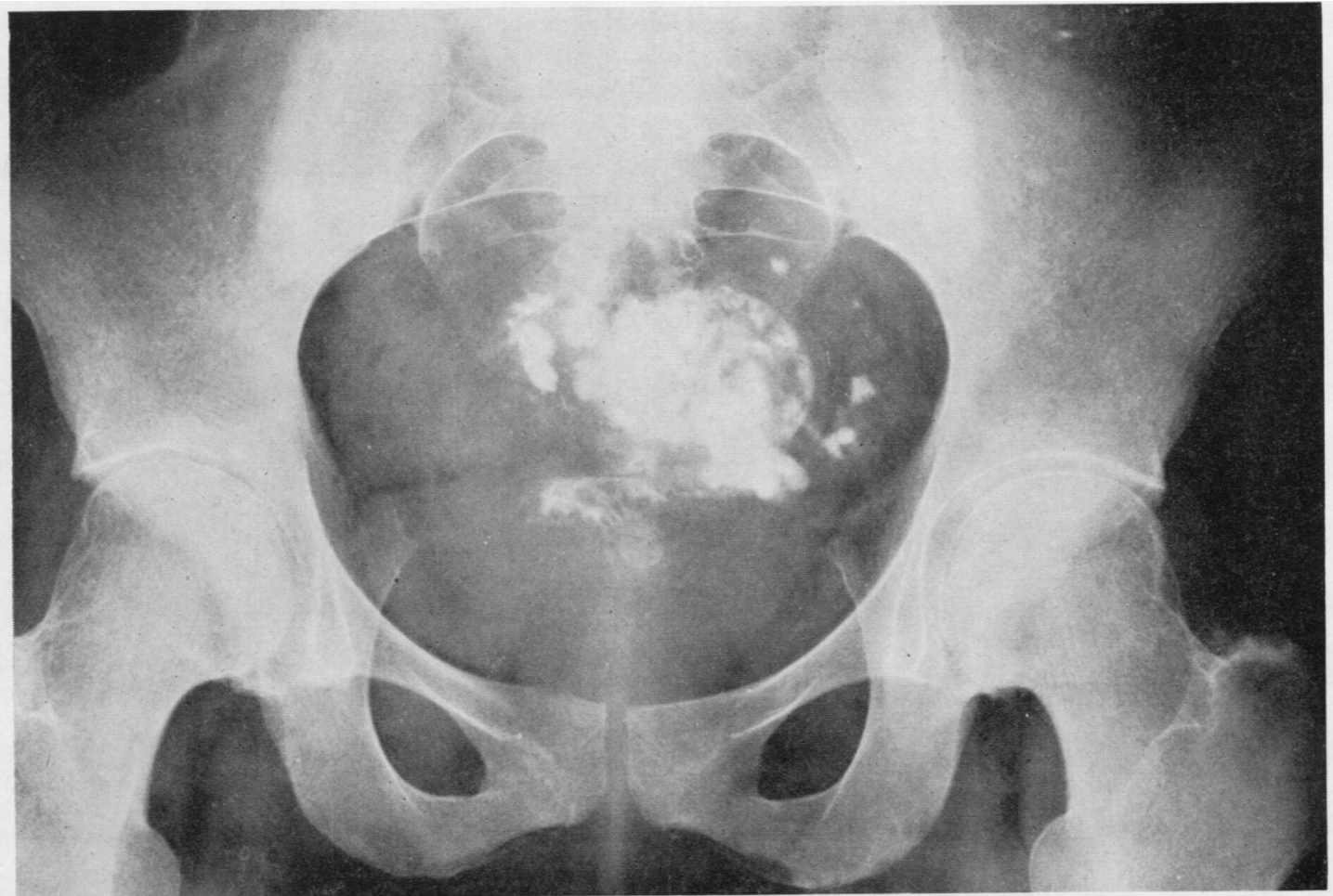

Fig. 3.-Case 13. pseudo-cystic lesions in acetabular and ischial margins seen in course of barium enema while the patient was symptom-free.

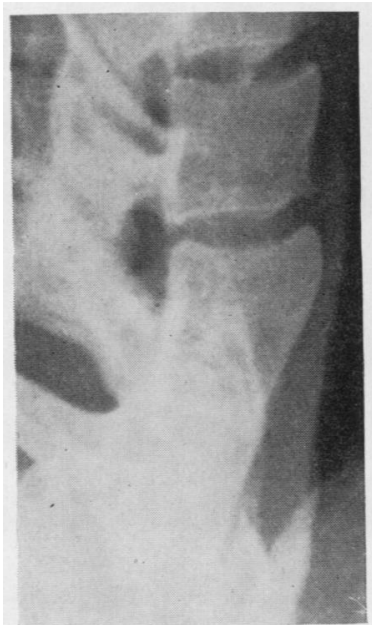

$$
1954
$$

1957

Fig. 4.-Case 13, anterior erosion of third cervical vertebra progressing between 1954 and 1957.

erythrocyte sedimentation rate, marked changes in the barium enema (Fig. 5), and minimal residua (slight limitation of dorsiflexion of the right wrist and extension of the neck) some 12 years from the onset of the disease.

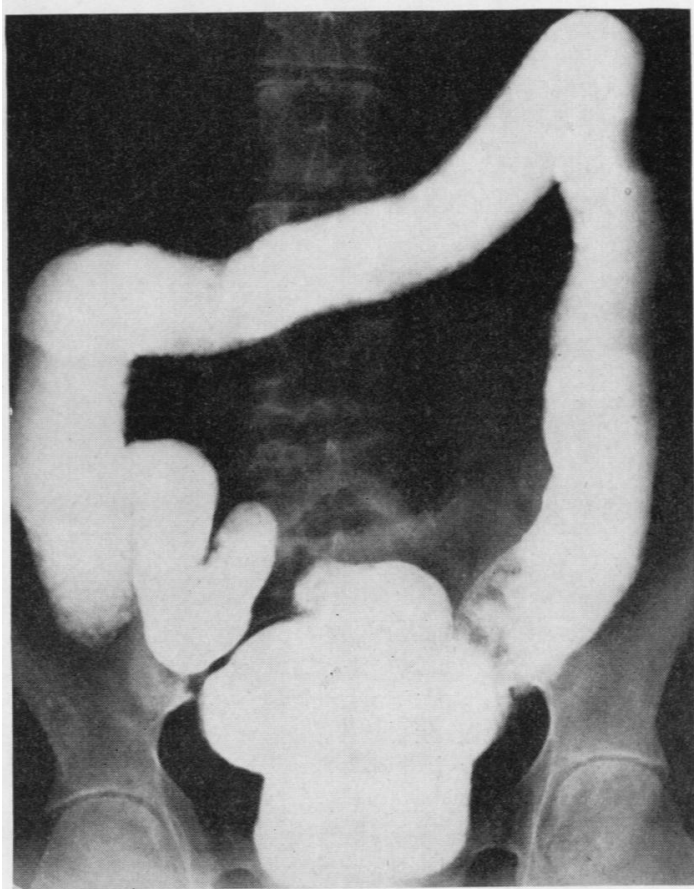

Fig. 5.-Case 13, barium enema during symptomless period. 
Remission might occur, usually coincident with improvement in the gut symptoms. Irreversible changes following cartilage erosion occurred in seventeen of the cases personally seen, but in four these changes were radiological only. In four cases there was slight clinical limitation of an elbow or wrist joint without radiological change. In only four patients were there gross changes such as are described in textbooks as "rheumatoid", and in two of these (Cases 14 and 35, Table II) the course was not completely typical for rheumatoid arthritis.

One of the latter two (Case 14) showed complete subsidence of the arthritis between the attacks of diarrhoea, with numerous exacerbations over a period of many years before irreversible changes occurred. Even then, the course was characterized by the exacerbation of arthritis accompanying increased gut activity, with erythema nodosum on one occasion (Fig. 6) and a rash resembling that seen in Still's disease on another. Sclerosis of the sacro-iliac joints occurred in addition to erosions seen in the hand $x$ rays.

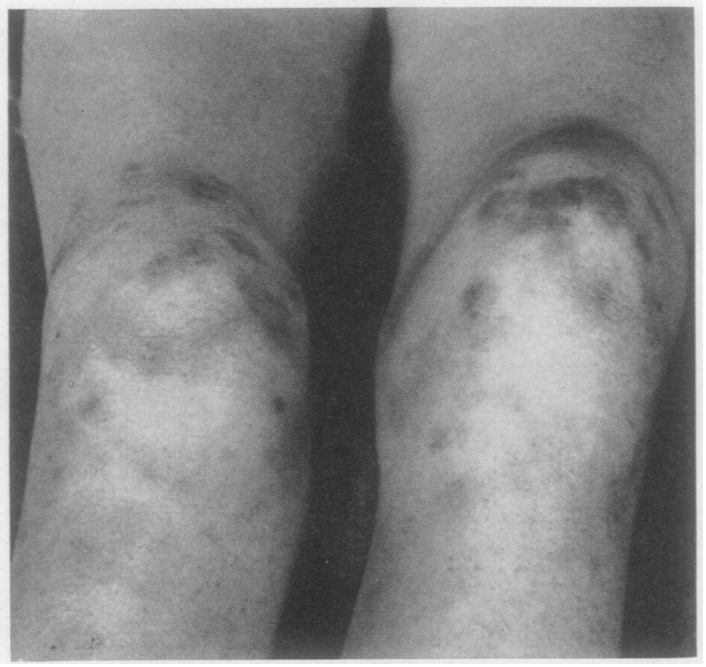

Fig. 6.-Case 14, erythema nodosum occurring with an acute exacerbation 24 years after first attack of arthritis and 27 years after onset of ulcerative colitis.

The second (Case 35) developed a mild arthritis one year after the onset of colitis followed by a severe generalized polyarthritis 2 years later, preceding an acute exacerbation of diarrhoea. Both conditions slowly improved and 6 years later this patient is in excellent general health, but he has some limitation of movement of both elbows and such severe hip residua that an arthrodesis has been performed on one side and an arthroplasty on the other. The hands appeared normal on clinica $\stackrel{D_{0}}{3}$ examination despite radiological changes (Fig. 7).

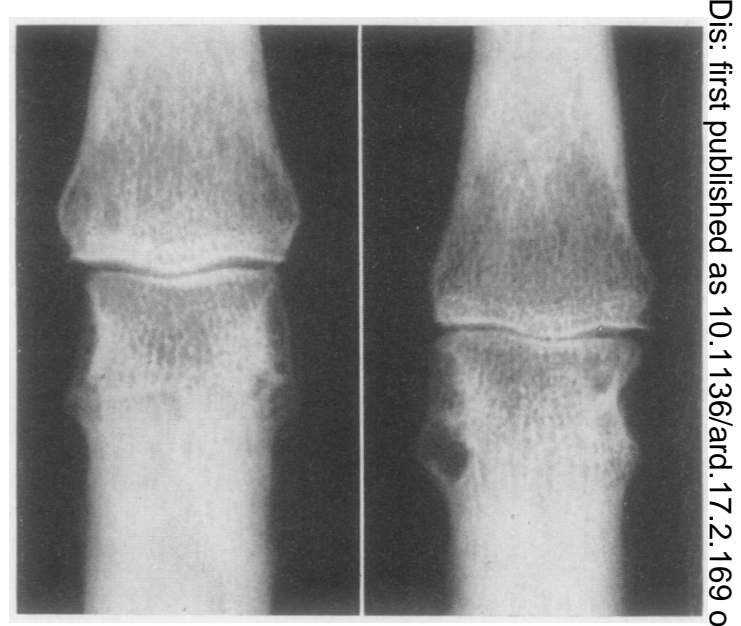

Fig. 7. - Case 35, $x$ ray of left third and fourth proximal interphalan geal joints showing radiological change without clinical residua.

In neither case was the differential agglutination test ever positive.

Two cases, both women, appeared to have typieak rheumatoid arthritis, in that there was gross syon-metrical involvement of the hands, feet, knees, o shoulders, and elbows, with radiological evidenoes of erosions before the onset of the colitis. In neither case was the development of colitis asso? ciated with any exacerbation of joint symptoms, and? no remission of joint symptoms followed spon $\overrightarrow{\overrightarrow{0}}$ taneous remission of the colitis in one and tota $\mathrm{B}$ colectomy in the other; in fact neither showed any? tendency to remission of arthritis at any time. Both cases showed tendon involvement, one had typicaw rheumatoid nodules, and in both the differentia? agglutination test was strongly positive. We regard these two patients as having two diseases con currently.

(c) Radiological Findings.-In many cases theseo do not differ from those of rheumatoid arthritis? In the early stages, osteoporosis only is seen, ando since remission so frequently occurs, this completely reversible change often disappears. Later, withos severe or longer maintained inflammation, periostitis may be seen (Fig. $1 b$ ) eventually resolving or welding with bone, and finally erosions occur. These may be slight and when healing occurs only slight defects may be left (Fig. 1c) or erosion may be severe enough to lead to complete loss of cartilage ands ankylosis as in Case 3 (Table II; Fig. 8, opposite).

In patients with backache, $x$ rays of the pelvis were taken, and in other cases, although no such 

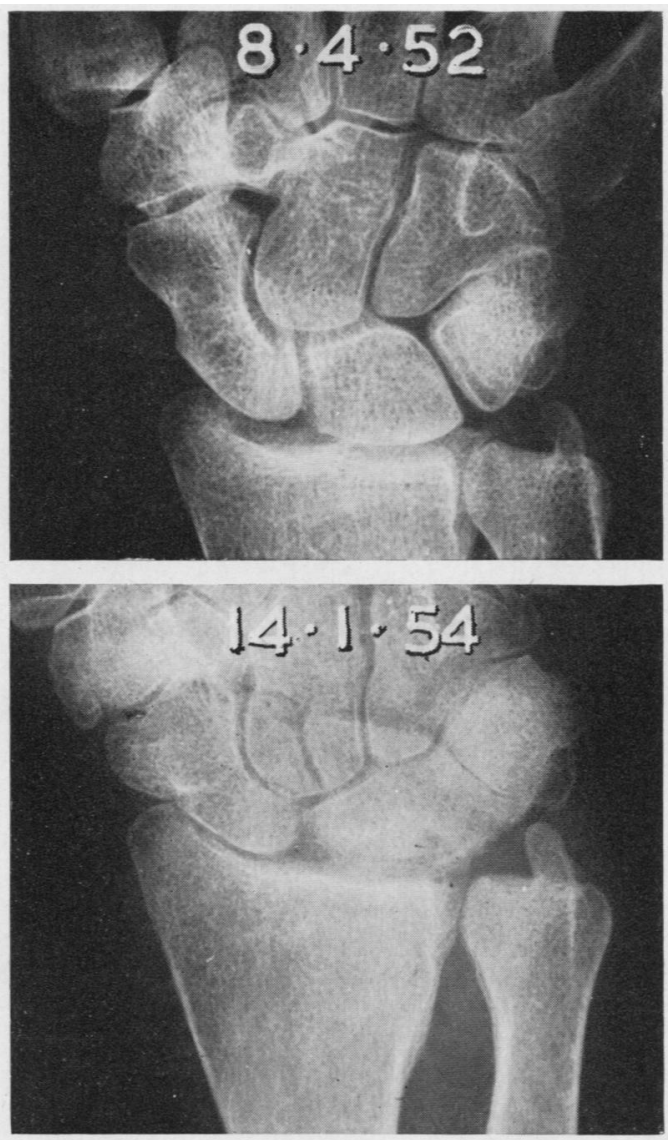

Fig. 8.-Case 3, $x$ ray of wrist showing progression of changes and periostitis from 1952 to 1954, despite remission of the disease.

examination was made, sacro-iliac lesions were looked for in $x$ rays of the pelvis taken in the course of barium enema studies and could occasionally be discerned; changes seen in the neck, trochanter, and ischial ramus of Case 13 are illustrated in Figs 3 and 4, and are indistinguishable from those which occur in ankylosing spondylitis.

(d) Histological Appearances. - The synovial membrane (three patients) is similar to that of rheumatoid arthritis, and not very different from that of the inflamed gut. There is synovial cell hyperplasia or loss of lining cells; in mild cases such as Case 13, a few lymphocytes and an occasional plasma cell and polymorph are seen in the subjacent membrane (Fig. 9). With more severe involvement, these changes are more pronounced, with much fibroblast proliferation and increased vascularity, with fibrin incorporated into the surface and more polymorphonuclears, lymphocytes, and plasma cells (Case 14, Fig. 10).

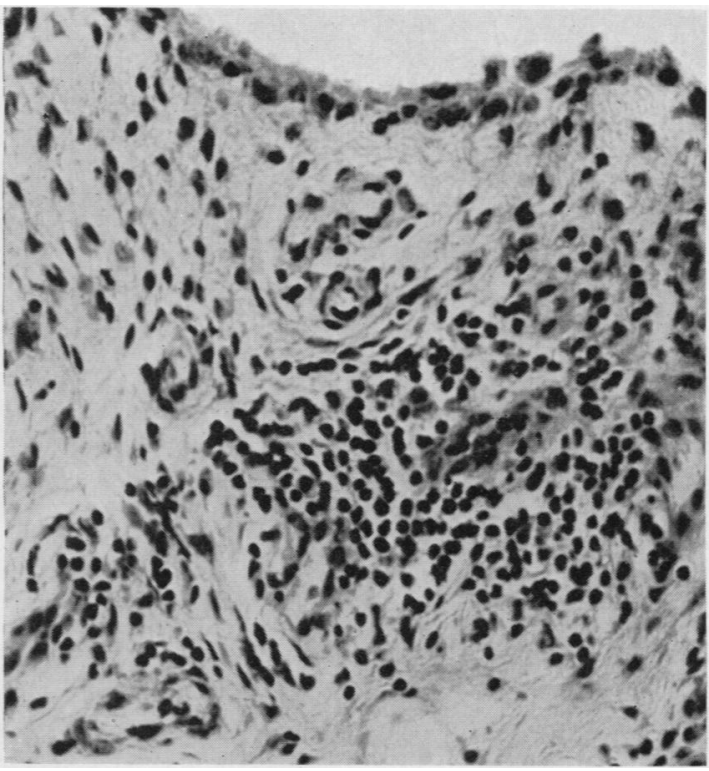

Fig. 9.-Case 13, synovial membrane of right wrist $3 \frac{1}{2}$ weeks after onset of swelling. Haematoxylin and eosin $\times 240$.

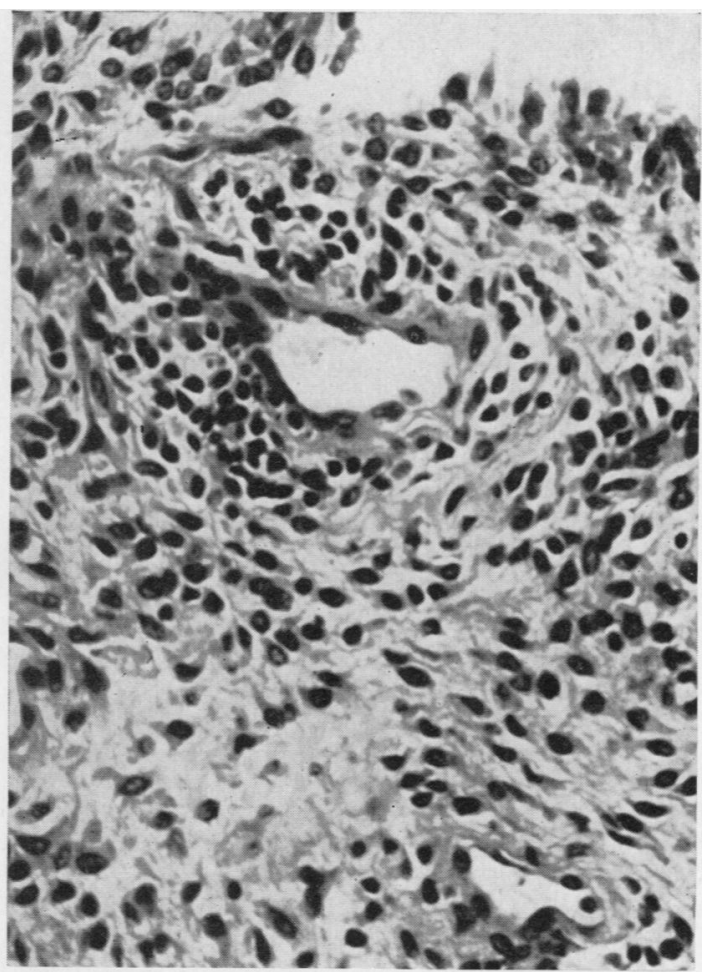

Fig. 10.-Case 14, synovial membrane, showing plasma cells, lymphocytes, and synovial cell hyperplasia. Haematoxylin and eosin $\times 285$. 


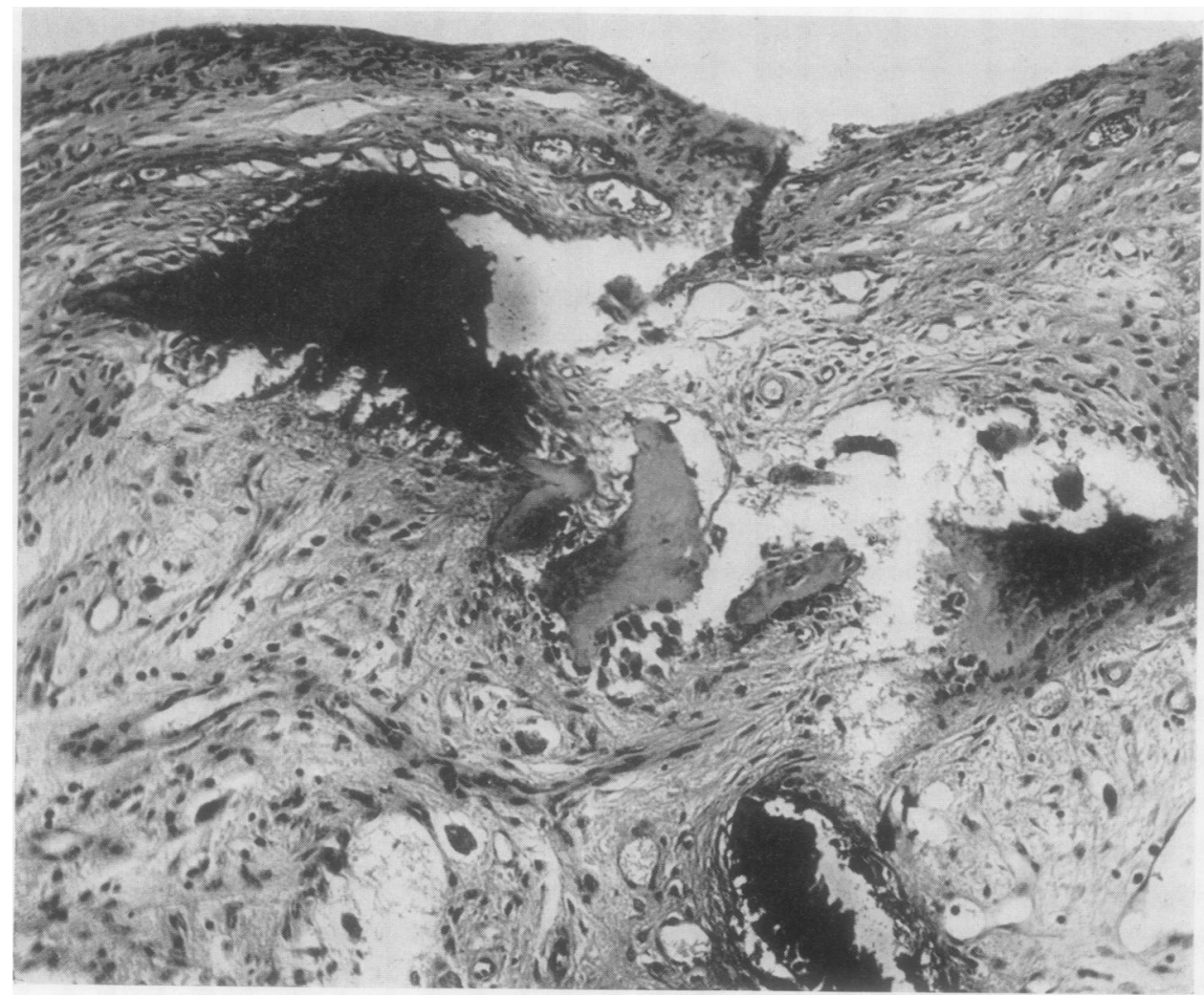

Fig. 11.-Case 14, synovial membrane, showing bone detritus. Haematoxylin and eosin $\times 135$.

In places the cartilage can be seen to be eroded, and fragments of necrotic cartilage and bone can be seen embedded in the synovial membrane (Case 14, Fig. 11). In one case, besides these changes, there were some epitheloid-looking cell collections but no caseation (Case 16, Table II, Fig. 12, opposite); both staining and culture for tuberculosis were negative.

(e) Serological Findings.-The Rose-Waaler test has been persistently negative in 25 out of 29 patients tested. In one (Case 15, Table II) it was positive on one occasion, but on retesting 3 weeks later it was within normal limits $(1: 8)$.

In only one case was a positive Rose test found in the complete absence of joint symptoms and residua. The two cases in which the differential agglutination test was persistently positive resemble classical rheumatoid arthritis, with tendon involvement in both and in one nodule formation.

The erythrocyte sedimentation rate was usually raised during the active episodes to high levels (e.g. $60-126 \mathrm{~mm} . / \mathrm{hr}$ Westergren) as might be expected with the large amount of gut affected. In remission, the erythrocyte sedimentation rate might $\overrightarrow{\overrightarrow{0}}$ be normal (e.g. Case 16, Fig. 13, opposite) or 3 raised despite absence of either gut or joint com-? plaints. Other investigations were either negative or non-specific (e.g. electrophoretic protein studies, agglutinations for Typhi- and Paratyphi A and B, Flexner, etc.).

(f) Synovial Fluid.-In ulcerative colitis patients this shows considerable variation (Table III, overleaf). In general it is not very different from thato found in patients with mild rheumatoid arthritis, as Ropes and Bauer (1953) have pointed out on the음 basis of fluids from up to five joints. We found in severely affected patients a rather higher maximal $\stackrel{\circ}{\circ}$ cell count than that reported by Ropes and Bauer N $(11,800$ per c.mm.), and in none of our cases was the N majority of cells present other than polymorpho- $\sigma$ nuclear. In most of our cases the protein content was low and fitted in well with the clinical finding of mild migratory synovitis, but the relative viscosity was unexpectedly low rather than high. These two characteristics generally have an inverse relation- 0 ship: a high polymorphonuclear cell count, low 
Fig. 12.-Case 16, synovial membrane, showing surface fibrin and epitheloid cell clusters but no caseation.

Haematoxylin and eosin $\times 200$.

relative viscosity, and high protein content usually accompany severe and chronic types of arthritis, and are accompanied by a low glucose content and a cloudy or granular acetic acid precipitate.

\section{Diagnosis}

The most common conditions from which this disease requires to be differentiated are rheumatic fever, rheumatoid arthritis, and ankylosing spondylitis, while Reiter's disease with diarrhoea, psoriatic arthritis, and polyarteritis nodosa may occasionally be mimicked. The difficulties in diagnosis are well illustrated by Case 16 (Table II), who developed arthritis while on treatment for what was thought to be tabes mesenterica. Not until 2 years later was a diagnosis of ulcerative colitis established.

Relation to Erythema Nodosum.-Erythema nodosum occurred in eight patients in the combined series (21 per cent.): other rashes recorded included pyoderma, eczema, urticaria, purpura, psoriasis, ulcerations, and various non-specified "rashes". Seven of the eight patients with erythema nodosum showed joint involvement at that time. In one the arthritis and erythema nodosum occurred with the

Fig. 13.-Case 16, chart showing normal E.S.R. during remission of arthritis.

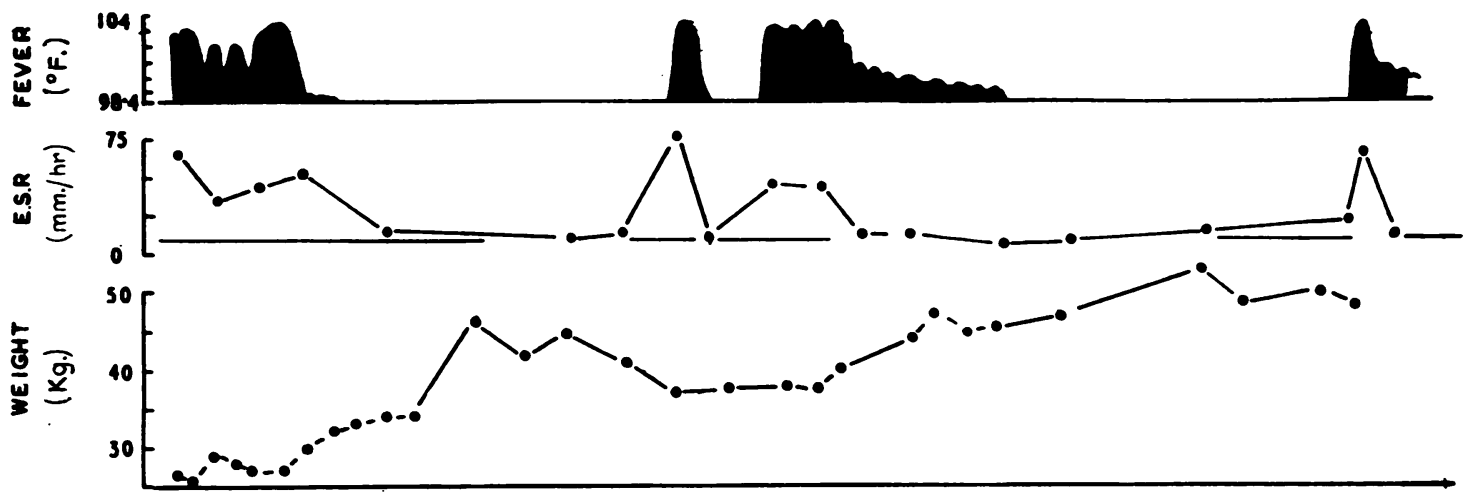

ARTHRTIS

DIARRHOEA

THERAPY
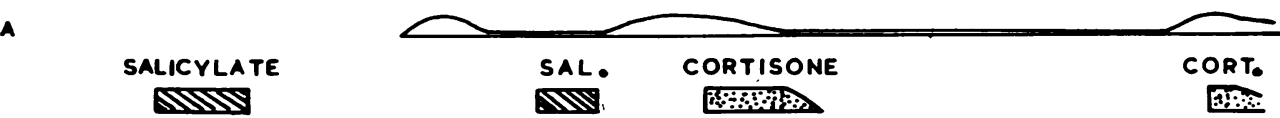

$\begin{array}{lll}1953 & \text { T1954 T1956 } & \text { T1957 }\end{array}$


TABLE III

SYNOVIAL FLUID IN ULCERATIVE COLITIS

\begin{tabular}{|c|c|c|c|c|c|}
\hline \multirow{2}{*}{$\begin{array}{l}\text { Case } \\
\text { No. }\end{array}$} & \multirow{2}{*}{$\begin{array}{c}\text { Protein } \\
\text { (g. per cent.) }\end{array}$} & \multirow{2}{*}{$\begin{array}{l}\text { Relative } \\
\text { Viscosity }\end{array}$} & \multicolumn{2}{|c|}{ Cells (c. mm.) } & \multirow[b]{2}{*}{ Growth } \\
\hline & & & Total & $\begin{array}{l}\text { Polymorphs } \\
\text { (per cent.) }\end{array}$ & \\
\hline 1 & $2 \cdot 0$ & - & - & 一 & 0 \\
\hline 2 & $2 \cdot 5$ & $3 \cdot 3$ & 4,400 & 75 & 0 \\
\hline 4 & $2 \cdot 5$ & - & 12,800 & 80 & - \\
\hline 5 & $3 \cdot 1$ & - & 28.000 & 91 & 0 \\
\hline 14 & $3 \cdot 8$ & $4 \cdot 1$ & 42.400 & 98 & 0 \\
\hline 15 & $5 \cdot 4$ & $4 \cdot 5$ & 10.000 & 90 & 0 \\
\hline 16 & $5 \cdot 5$ & $7 \cdot 7$ & 4,000 & - & 0 \\
\hline $\begin{array}{c}\text { Ropes and Bauer (1953) } \\
\text { Three to five cases }\end{array}$ & $2 \cdot 9$ to $5 \cdot 6$ & $8 \cdot 2$ to $13 \cdot 0$ & 350 to 11,800 & 0 to 97 & 0 \\
\hline
\end{tabular}

onset of diarrhoea and settled in a week. In Case 15

(Table II), erythema nodosum developed 3 months

as pericarditis and polyarthritis, after an attack of ? after the onset of diarrhoea and on the same day episcleritis (Fig. 14). The antistreptolysin titre later
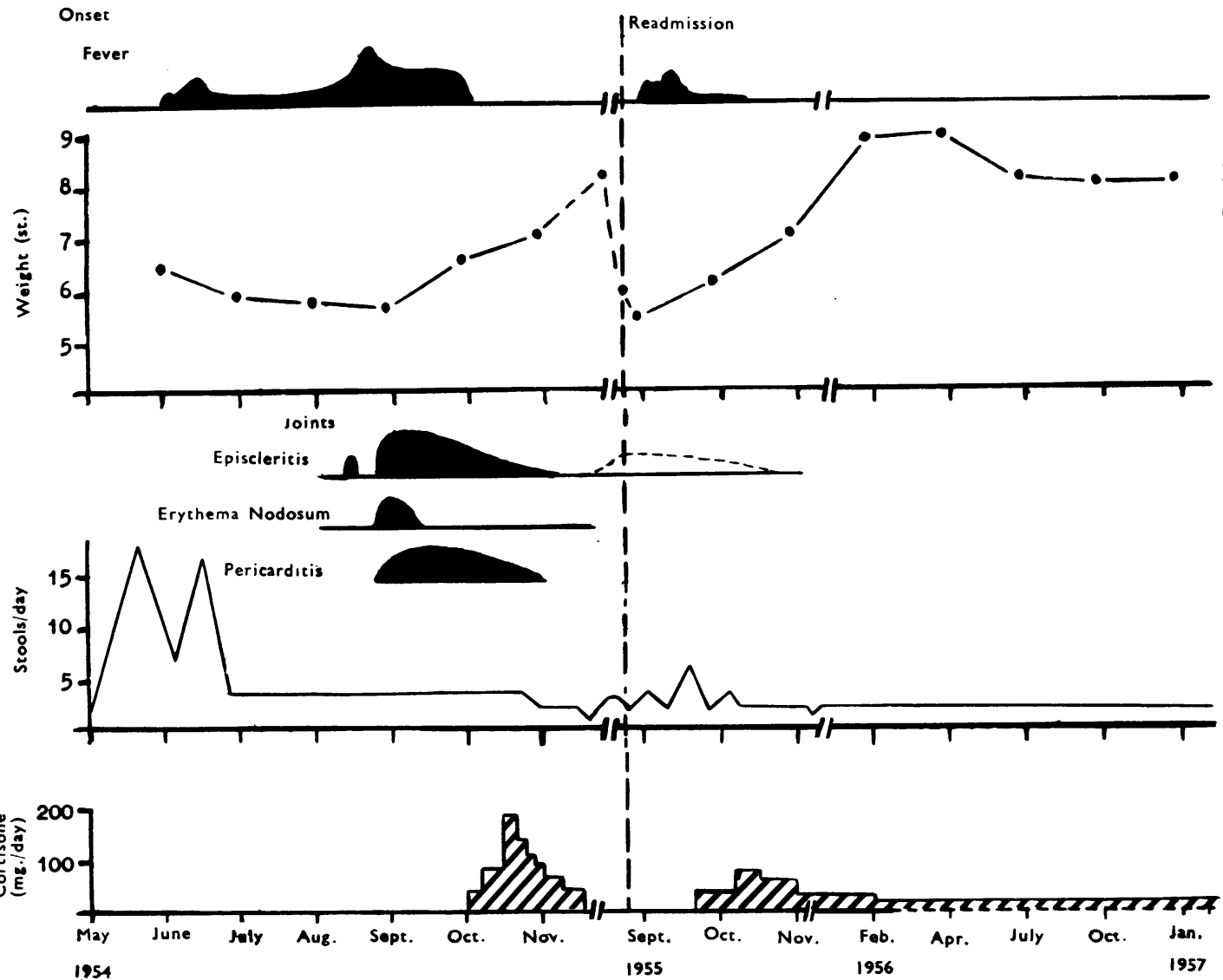

Fig. 14.-Case 15 chart showing response to cortisone therapy 
sum occurred 3 months after the onset of colitis and the arthritis at about the same time. In two cases it occurred with exacerbations of colitis 13 and 16 years after the first onset of symptoms, and was associated with an acute arthritis which settled without residua in a few weeks. In another case with joint involvement, it was present with arthritis 23 years after the onset of colitis. The spots tended to appear on the knees more often than in erythema nodosum without ulcerative colitis, and sometimes as in Case 14 they recurred. The multiple recurrence of erythema nodosum with ulcerative colitis has been noted by Wright and Kenwood (1956) and by Sulzberger (1945); ulceration, as noted by Kelley and Logan (1956), was not seen in this series.

Relation to Rheumatic Fever.-This was said to have occurred in five of the 98 Hammersmith and Taplow patients reviewed, including two of those with arthritis (Cases 1 and 14). In three cases this occurred in childhood (at 6,10 , and 30 years before the onset of ulcerative colitis) and in two others at the age of 24 and 18 years (12 and 7 years before the onset of colitis). In none of these five cases were cardiac residua noted. Although it seems probable that some of these were in fact rheumatic fever attacks, it is also possible that they were prodromal arthritis associated with the gut lesion, since in other patients the joint disease has been so diagnosed (Case 13) before the significance of the occasional loose stool was appreciated. There is a widespread but unfounded belief that a fever which responds to salicylates is rheumatic. The fever of ulcerative colitis responds well to aspirin (Case 16, Fig. 15) and to cortisone (Case 15, Fig. 14) but not to antibiotics.

Relation to Gut Exacerbations.-While arthritis may precede obvious diarrhoea, in most instances diarrhoea and arthritis occur together or arthritis follows an exacerbation of gut symptoms. The majority of patients in this series had mild or

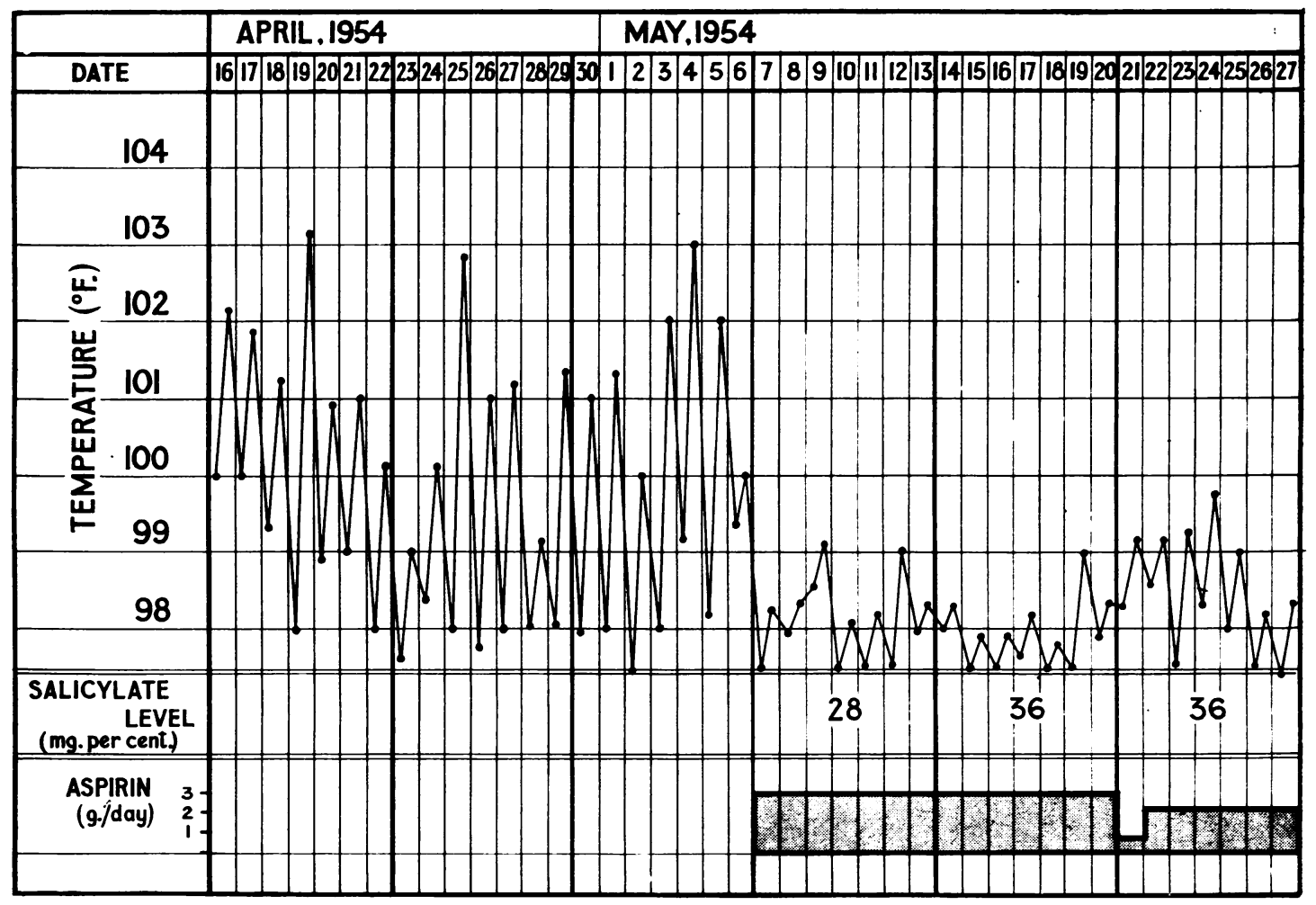

Fig. 15.-Case 16. chart showing response to aspirin therapy. 
moderate ulcerative colitis with fairly frequent remissions. It seems probable, however, that the gut lesion may be "active" at a subclinical level and that arthritis, like the skin complications, is always secondary to the intestinal disease. Thus in Case 13, with no bowel complaints and with two normally-formed motions per day, a barium enema disclosed gross colonic disease (Fig. 5, p. 173). In only one case could the ulcerative colitis be regarded as fulminating (Case 30) and this patient developed arthritis 11 months after a sub-total colectomy, at which time she showed a persistently inflamed recto-sigmoid junction.

Relation to Ileostomy, Colectomy, etc.-Seven patients had colectomy performed and two a partial colectomy. In other reported series (e.g. Brooke, 1954) colectomy led to remission of joint symptoms in seven out of eight cases. Brooke (1956) noted arthritis in seventeen patients. Of the fourteen who survived the operation, two had an occasional arthralgia, one a brief recurrence, and one no joint remission. Brooke (1954) also noted that arthritis might start after the removal of the colon. Of the patients here reported, one developed severe generalized arthritis for the first time after colectomy, associated with a fistula at the site of the ileostomy; this finally settled down after 3 years, but left residual limitation (Case 3). In another patient the arthritis had settled spontaneously before an ileostomy and total colectomy were successfully performed; since then the patient has had one attack of pain and swelling in an elbow, which subsided leaving limitation of extension of that elbow by $15^{\circ}$ but no radiological change. Others have done as well with ileostomy alone.

Arthritis may not appear until as long as 3 years after ileostomy, it may persist for 11 years and yet be cured by colectomy (Campbell, 1938). Bargen, Lindahl, Ashburn, and Pemberton (1943) found that eleven patients with recurrent chronic arthritis after ileostomy did better than five in which the arthritis antedated the operation.

Eight patients received steroid therapy, and in all except one (Case 14) a satisfactory remission of arthritis occurred, although mild bowel symptoms persisted in two. Thus it is suggested that the arthritis is likely to improve if the bowel symptoms improve.

\section{Selected Case Reports}

Case 1 (Table II), a boy aged 16 in 1955, was first seen complaining of pain in the hips, knees, and feet of 6 months' duration. He had had painful knees for 3 months when aged 14 , diagnosed as sub-acute rheu- matism, and at the age of 10 he had had pain and swelling of one knee which persisted for one month and was diagnosed as rheumatic fever.

On examination he showed pain and limitation of both hips, soft tissue swelling, and effusion into both knees, and some tenderness of both heels. There was $\overrightarrow{\vec{F}}$ no limitation of back movement. His general conditionwas excellent. The erythrocyte sedimentation rate was $\frac{C}{\circ}$ $61 \mathrm{~mm}$./hr. Plasma: albumin $2 \cdot 8$ per cent., globulin 5.3 per cent. $X$ rays showed complete fusion of both $\vec{\sigma}$ sacro-iliac joints (Fig. 2). The peripheral joints were treated with deep $x$-ray therapy with good effect, but ${ }_{\omega}$ 7 months later he developed diarrhoea with blood in the stools and marked loss of weight. With this he had a. relapse of arthritis affecting the knees, ankles, and heels. $\overrightarrow{\vec{\omega}}$ On re-admission in January, 1956, he showed effusions ${ }_{\mathcal{O}}^{\omega}$ and soft tissue swelling into the right knee, soft tissue swelling of the left ankle, and tenderness of both heels.

Positive investigations included erythrocyte sedimen- $\vec{V}$ tation rate $60 \mathrm{~mm}$./hr, plasma proteins $8.2 \mathrm{~g}$. per cent., i albumin $3.3 \mathrm{~g}$. per cent.. globulin $4.9 \mathrm{~g}$. per cent., and $\overrightarrow{-}$ sigmoidoscopy typical of ulcerative colitis. All othere investigations, including those for T.A.B.A. agglutinins, 은 stools, pathogens, L.E. factor, and Rose-Waaler test ${ }_{-}$ were negative.

$X$ rays of the knees now showed erosions of both tibial plateaux, and the os calcis shows incomplete ${ }^{\Phi}$ erosions beneath the insertion of the Achilles tendon. $\vec{\bullet}$

As he showed no tendency to improve on a conservative regime, cortisone therapy was commenced on April, 1956. He has continued on this regime until theo present (1958) and on $75 \mathrm{mg}$./day has no residual signs of arthritis and no limitation of back movement and, is in excellent general condition. $\mathrm{He}$ is maintaining his weight satisfactorily, but still has slight diarrhoea (two $\mathbb{Q}$ to three motions a day with occasional blood). Sigmoidoscopy is still abnormal and the erythrocyte sedi-음 mentation rate is now $3 \mathrm{~mm}$. $/ \mathrm{hr}$.

Case 3 (Table II), a woman aged 38 in August, 1951, was first seen with a history that she had developed ulcerative colitis in November, 1949, which had per- sisted in a continuously active state until an ileostomy 3 was performed in October, 1950, followed by a complete colectomy in January, 1951. Shortly after this she developed a fistula at the site of the ileostomy, and in May, 1951, she developed a severe generalized acute의 arthritis, which was still evident on admission.

On examination she showed involvement of the neck, both shoulders, left elbow, both wrists, and second proximal interphalangeal joint of the second right toe, $\sigma$ and in addition she had flexor tendon-sheath effusion of $N$ the right hand. The erythrocyte sedimentation rate was $120 \mathrm{~mm}$./hr, haemoglobin $13.6 \mathrm{~g}$. per cent., and differen- $\omega$ tial agglutination test negative $(1: 2)$. She was treated with a short course of ACTH (for 5 days) and intensiveo physiotherapy.

The ileostomy was repaired in October and she was? finally discharged in December, 1951, much improved, 0 with little residual trouble from the arthritis, apart fromo limitation of both wrist joints. 
She remained well until August, 1953, when she had a recurrence of the fistula at the site of the ileostomy, and this was followed by recurrence of arthritis mainly in the hands, knees, and left foot. This decreased in intensity but she still had some residual swelling with a very painful swollen right wrist when admitted for repair of the fistula in January, 1954. $X$ rays of the wrist showed erosions (Fig. 8). She was again treated with ACTH, and there was an excellent response as regards the joints, and by the time of discharge in April, 1954, her joints had settled to normal, apart from residual limitation of the wrists, and this was the state when she was last seen in November, 1956.

Case 8 (Table II), a woman aged 44 when first seen in 1951 had had diarrhoea for 10 years; in the last 6 months it had become worse and was accompanied by acute arthritis of the right foot and left shoulder.

On examination, the left shoulder, both acromioclavicular joints, right ankle, one metatarsophalangeal joint, and one distal interphalangeal joint were involved (Fig. 1a). $X$ rays showed periostitis and erosion (Fig. 1b). The erythrocyte sedimentation rate was $65 \mathrm{~mm}$./hr, differential agglutination test $1: 4$. Sigmoidoscopy and barium enema were positive. The arthritis lasted for 6 months only, but in the last 7 years she has had recurrent mild bouts of diarrhoea with occasional involvement of the shoulder, the left first metacarpophalangeal joint, and the third left distal interphalangeal joint. Now at the age of 51 she shows no clinical residua; the erythrocyte sedimentation rate is $20 \mathrm{~mm}$./hr, and the differential agglutination test $1: 2$, but $x$ rays show a healed erosion in a metatarsal head (Fig. 1c).

Case 13 (Table II), a girl aged 14 when first seen in February, 1951, had first developed a flitting arthritis 6 years before at the age of 8 ; the arthritis was associated with fever and followed by diarrhoea with blood in the stools. This illness, diagnosed as rheumatic fever, had lasted for 3 months. Some 14 months later she had a further bout of arthritis in the knees, again followed by diarrhoea, which persisted for about 6 months. One year later, in October, 1948, she had further polyarthritis involving elbows, ankles, and knees, followed again by diarrhoea, both remitting after 3 months. She had two further slight flares of knees and ankles in March and October, 1950, associated each time with mild diarrhoea.

In February, 1951, she gave a history of flitting arthralgia for some 3 weeks, persistent pain and swelling in right wrist, and diarrhoea with blood in the stools. At this time the erythrocyte sedimentation rate was 60 $\mathrm{mm} . / \mathrm{hr}$ and the differential agglutination test $1: 2$. A biopsy specimen of the synovial membrane of the right wrist was compatible with rheumatoid arthritis (Fig. 9). She rapidly improved but later in the year developed a brief synovitis of the left ankle not associated with diarrhoea.

She has since taken up an active career of nursing and her general condition has remained excellent despite a persistently high erythrocyte sedimentation rate. At a follow-up examination in January, 1957, she was found to be in good health, passing two well-formed stools per day but with slight residual limitation of neck and right wrist movement. The back movement was good. The erythrocyte sedimentation rate was $47 \mathrm{~mm}$./hr, and the differential agglutination test again negative. A barium enema, however, showed typical ulcerative colitis affecting the whole colon (Fig. 5). Bilateral sacro-iliitis, erosions of the ischia, and great trochanters (all symptomless), and cystic lesions in the acetabular margins were seen radiologically (Fig. 3). In the neck there was an anterior erosion of the third cervical vertebra of the type described by Romanus (Fig. 4).

Case 14 (Table II), a woman aged 42 when first seen in 1948, gave a history that she first developed ulcerative colitis at the age of 19 , and that this was followed by arthritis at the age of 24 . From then until 1935 she had bouts of colitis associated with flitting arthritis mainly in the knees lasting about 2 months almost every year. Between attacks she was completely well.

6 weeks before her attendance in 1948 she had developed severe colitis, followed 2 weeks later by arthritis of the knees and right wrist and erythema nodosum (Fig. 6). The erythrocyte sedimentation rate was 107 $\mathrm{mm}$. $/ \mathrm{hr}$, and the radiological appearance of the joints was compatible with rheumatoid arthritis. She slowly improved on a conservative regime, but some 4 months later relapsed again with further arthritis involving the left wrist and shoulders and a recurrence of the rash. Again she improved, only to relapse 3 months later with a severe attack of colitis followed by much more generalized arthritis, now involving the proximal interphalangeal joints of both wrists and shoulders as well as the knees. Since that time she has shown no complete remission of either the colitis or the arthritis, though these have varied from time to time. From August, 1952 , she had residual deformities in the proximal interphalangeal joints of all fingers, the third and fourth metacarpophalangeal joints of both hands, wrists, and knees, and the right mid-tarsal joint. The erythrocyte sedimentation rate was $55 \mathrm{~mm} . / \mathrm{hr}$, and differential agglutination test negative $(1: 2)$.

She then improved somewhat, clinically, but in 1954 the arthritis again became worse with further involvement of left wrist and right shoulder, large effusions into the knees, and for the first time a skin rash like that seen in Still's disease.

In 1956 she was put on to delta-cortisone with some improvement. When seen in 1957, she had no rash, four to five motions a day, and clinical involvement of the knees, with effusion of the right elbow, left ankle, wrists, metacarpophalangeal second and third right and left, proximal interphalangeal third left, and second left proximal interphalangeal toe joint. The erythrocyte sedimentation rate was $60 \mathrm{~mm} . / \mathrm{hr}$, and differential agglutination test $1: 2$. $X$ rays showed erosions of numerous joints and obliterative erosion and sclerosis of the sacro-iliac joint. 
Case 16, a boy aged 12 when admitted to another hospital in December, 1951, with a 3-month history of weight loss, abdominal pain, and vomiting, was thought to be suffering from tabes mesenterica and was treated with streptomycin and P.A.S. Shortly after admission he developed bilateral knee effusions which were treated with salicylates with improvement. He was discharged 6 months later but re-admitted after 3 months for removal of an "acute appendix": at this time no glands were found in the abdomen. He developed a wound abscess and this was followed by development of an abdominal sinus. He again had troublesome knee effusions, and a biopsy was taken of one knee (Fig. 12). He was transferred to Taplow in January, 1953, as a case of Still's disease with pain and swelling of the knees, together with persistent colic and a discharging abdominal sinus. There were bilateral joint effusions but no other abnormality. A barium meal and fat balance were normal. The erythrocyte sedimentation rate was raised and he ran an intermittent fever. Differential agglutination test $1: 1$. The joint fluid contained 4,000 cells/c.mm., relative viscosity $7 \cdot 7$, protein $5 \cdot 5 \mathrm{~g}$. per cent., culture negative.

In view of the persistent sinus and colic the fistula leading to the appendicular stump was excised in April, 1953. However, post-operatively his pyrexia and arthritis persisted. He was treated with salicylates with some improvement (Fig. 15).

In April, 1954, he had a short bout of diarrhoea and was re-admitted for one month in August, 1954, because of recurrence of arthritis involving the elbows, knees, wrists and ankles. At this time he was pyrexial, erythrocyte sedimentation rate $45 \mathrm{~mm}$./ hr, differential agglutination test $1: 2$. He rapidly improved on salicylates.

He was re-admitted in February, 1955, with diarrhoea, severe for one month and probably mild for three previous months. Sigmoidoscopy was negative but a barium enema showed ulceration and polypi in the transverse and descending colon. He was treated with sulphasuxidine and a short course of cortisone with a satisfactory response, and was finally discharged on June 24 , 1955.

He remained well until later in 1956 when he developed a mild temporary exacerbation of arthritis involving both knees and right elbow, together with marked loss of weight. Differential agglutination test $1: 8$. No $x$-ray or clinical joint residua. No sacro-iliac change.

\section{Discussion}

The most interesting feature of this syndrome is its relationship to rheumatoid arthritis, Reiter's disease, and ankylosing spondylitis. Since in all cases except two, the course of the joint lesions was very different from that of rheumatoid arthritis and the Rose test was usually negative, these cases can hardly represent the purely coincidental association of the two diseases. If, however, this syndrome is, e.g. rheumatoid arthritis precipitated by colitis, the colitis or colitic diathesis must modify the rheumatoid arthritis considerably to produce the differences noted above.
Both Reiter's syndrome and ankylosing spondylitis occur predominantly in males, whereas only two of our six cases with sacro-iliac involvement were males. Episcleritis and iritis were seen only once, and balanitis, keratodermia, urethritis, and aortitis $\overrightarrow{\vec{F}}$ not at all. It seems most probable that this is a separate disease of the joints of a somewhat similar nature to those noted above, caused by the same factors as those that produce the disease of the gut or perhaps secondary to gut disease. Disease of the gut may produce a secondary arthritis, but this is \& unlikely because, apart from the dubious joint $\vec{\nabla}$ troubles of Whipple's syndrome and the acute rheumatic fever-like sequelae of dysentery, gut $\vec{\omega}$ inflammation does not produce secondary arthritis with any noticeable frequency. The clear association in some instances with erythema nodosum, and particularly the acute arthritis occurring only i with this in some cases, suggests an "allergic" basis, i.e. the active participation of an antibody-forming mechanism.

\section{Summary}

(1) 37 patients suffering from both arthritis and $\vec{\theta}$ colitis have been reviewed, thirty of whom were 1 seen personally.

(2) In the majority, the colitis was of mild moderate severity. The arthritis tended to be recurrent mild and often migratory synovitis, localizing in one or two of the joints longest affected, and frequently remitting. Only rarely did a severe generalized form of arthritis occur.

(3) Nodule formation with a persistently positive differential agglutination titre was seen in only two cases.

(4) Radiological changes did not differ from those seen in rheumatoid arthritis, although healing tended to occur more frequently and there was a moderately high incidence of sacro-iliac involvement.

(5) In view of the nature of the arthritis together with the negative differential agglutination test usually found, it is concluded that a separate form 5 of arthritis is associated with the ulcerative colitis; $\frac{D}{O}$ it is similar to that occurring acutely in erythema nodosum due to other causes, but it may last longer $N$ and may recur; in such cases chronic residual changes closely resembling those of rheumatoid arthritis may be seen.

We wish to thank our colleagues at the Postgraduateco Medical School, London, and the Canadian Red Cross $\mathbb{D}$ Hospital, Taplow, particularly Dr. Sheila Sherlock and $\stackrel{\mathcal{f}}{?}$ Dr. George Hadley, who allowed us to use data from their $\square$ cases and also referred cases to us; also Mr. G. P. Arden o who kindly performed the biopsies for us. 


\section{ARTHRITIS ASSOCIATED WITH ULCERATIVE COLITIS}

We are very grateful to Dr. N. F. Coghill of the West Middlesex Hospital and Dr. G. Kellock of the Central Middlesex Hospital, who in addition to reviewing their cases of ulcerative colitis at our request, very kindly arranged for us to see particular cases and obtain blood samples and $x$ rays, and allowed us to use these data.

We should also like to thank Dr. Francis Scott for the frequent repetitions of the differential agglutination test examinations which he undertook.

\section{REFERENCES}

Bargen, J. A., cited by Hench (1935)

Lindahl, W. W.. Ashburn, F S. and Pemberton, J. de J. (1943). Ann. intern. Med., 18, 43

Brooke, B. N. (1954). "Ulcerative Colitis and its Surgical Treatment." Livingstone, Edinburgh

(1956). Lancet, 2, 532

Brown, M. L., Kasich A. M., and Weingarten, B. (1951). Amer. J. dig. Dis., 18, 52.

Bywaters, E. G. L. (1954). Ann. rheum. Dis., 13, 42.

Campbell, S. J. (1938). Proc. Mayo Clin., 13, 385.

Comfort, M. W., Bargen, J. A., and Morlock, C. G. (1938). Med. Clin. N. Amer., 22, 1089.

Comroe, B. I. (1953). "Arthritis and Allied Conditions", 5th ed., ed. J. L. Hollander. Kimpton, London.

Copeman, W. S. C. (1955). "Textbook of the Rheumatic Diseases", 2nd ed. Livingstone, Edinburgh

Cullinan, E. R. and MacDougall, I. P. (1957). Lancet, 1, 487.

Dennis, C., and Karlson, K. E. (1952). Surgery, 32, 892.

Empire Rheumatism Council (1950). Ann. rheum. Dis., 9, Supplement.

Fletcher, E. (1951). "Medical Disorders of the Locomotor System, Including the Rheumatic Diseases", 2nd ed. Livingstone,

Hench, P. S (1935) “Nelson's Loose-leaf Surgery”, p. 104

- and others (1936). Ann. intern. Med., 10, 754 (Rheumatism Review)

(1940). Ibid., 13, 1655, 1837 (Rheumatism Review). (1941). Ibid,. 14, 1383, 1631 (Rheumatism Review)

Kelley, M. L., and Logan, V. W. (1956). Gastroenterology, 31, 285.

Kellgren, J. H., and Lawrence, J. S. (1956). Ann. rheum. Dis., 15, 1.

(1953). Ibid., 12, 5.

Kirsner J. B. Palmer, W. L., Maimon, S. N., and Ricketts, W. E.

(1948). J. Amer. med. Ass., 137, 922.
Sklar, M., and Paimer, W. L. (1957). Amer. J. Med., 22, 264.

Melrose, A. G. (1955). Gastroenterology, 29, 1055.

Rice-Oxley, J. M., and Truelove, S. (1950) Lancet, 1, 607 and 663.

Robinson, W. D., and eleven others (1953). Ann. intern. Med., 39, nos. 3 and 4, 498, 757 (Tenth Rheumatism Review) 39, (1956). Ann. intern. Med., 45, nos. 5 and 6, 831, 1059 (Eleventh Rheumatism Review)

Romanus, R., and Ydén, S. (1955). "Pelvo-Spondylitis Ossificans." Munksgaavel, Copenhagen.

Ropes, M. W., and Bauer, W. (1953). "Synovial Fluid Changes in Joint Disease." Commonwealth Fund, Harvard University Press.

Scott, F. E. T. (1952). Lancet, 1, 392.

Sloan, W. P., Bargen, J. A., and Gage, R. P. (1950). Gastroenterology. 16, 25 .

Sulzberger, F. M. (1945). New Engl. J. Med., 233, 87

Wright, F. H., and Kenwood, J. F. (1956). Pediatrics, 18, 663.

\section{Arthrite associée à la colite ulcérative RÉSUMÉ}

(1) On a re-examiné 37 malades, dont 30 personnellement, tous atteints d'arthrite et de colite ulcérative.

(2) Chez la plupart d'entre eux, la colite était benigne ou modérée. L'arthrite tendait à présenter la forme de synovite benigne, recurrente et souvent migrante, souvent localisée dans une ou deux des articulations atteintes le plus longtemps, avec de fréquentes remissions. La forme sévère d'arthrite généralisée n'apparaissait que rarement.

(3) La formation de nodules avec la réaction d'agglutination différentielle toujours positive n'a été observée que dans deux cas.

(4) L'image radiologique n'était pas différent de celui observé dans l'arthrite rhumatismale, bien que la guérison tendait à se produire plus souvent et l'implication sacro-iliaque était assez fréquente.

(5) En vue de la nature de l'arthrite, ainsi que de la réaction d'agglutination différentielle habituellement négative, on conclut que cette arthrite, associée à la colite ulcérative, représente une forme à part; elle ressemble au type aigu survenant au cours de l'érythème noueux du aux autres causes, mais peut durer plus longtemps et peut récidiver; dans ces cas on peut observer des altérations chroniques résiduelles se paraissant beaucoup à celles de l'arthrite rhumatismale.

\section{Artritis asociada a la colitis ulcerativa SUMARIO}

(1) Se revistaron 37 enfermos con artritis y colitis ulcerativa; 30 de ellos fueron examinados personalmente.

(2) En la mayoría de ellos, la colitis fué benigna o moderada. La artritis tendía a presentar la forma de sinovitis benigna, recurrente $y$, a menudo, migrante, frecuentemente en una o dos articulaciones afectas desde mucho tiempo, con remisiones frecuentes. La forma de poliartritis generalizada severa fué muy rara.

(3) La formación de nódulos con una reacción de aglutinación diferencial siempre positiva fué observada tan sólo en dos casos.

(4) Las alteraciones radiológicas no fueron diferentes de las observadas en la artritis reumatoide, pero curas tendian a producirse más a menudo y la implicación sacro-ilíaca fué frecuente.

(5) En vista de la naturaleza de la artritis, así como de la reacción de aglutinación diferencial generalmente negativa, se concluye que esta artritis, asociada a la colitis ulcerativa, es una forma aparte; esta forma se parece al tipo agudo que ocurre en el eritema nodoso debido a otras causas, pero puede durar más tiempo y puede reincidir; en tales casos se pueden ver alteraciones crónicas residuales muy parecidas a las de la artritis reumatoide. 